\title{
E-Catalogue Berbasis Android
}

\author{
Rahma Annissa ${ }^{1)}$, Evi Yulianti ${ }^{2)}$ \\ ${ }^{12)}$ Program Studi Sistem Informasi Universitas Indo Global Mandiri \\ Jl. Jend. Sudirman No. 629 KM.4 Palembang Kode Pos 30129 \\ Email : rahmaannissq12345@gmail.com ${ }^{1)}$, evi.uigm@gmail.com $^{2)}$
}

\begin{abstract}
Minimarket Murah Meriah is a low-cost minimarket that exists in Palembang. Minimarket Murah Meriah distributes its products through offline media with brochures and banners as a means of product promotion. In the modern era of mobile devices is growing very rapidly and also the evolution of mobile devices increases with the number of mobile platform applications. One of the most developed so far is Android. With the rapid development of information technology, a business can improve performance and improve the quality of its business by providing convenience and convenience for customers, without spending large costs to promote a product. To overcome this problem, researchers need a study to create a cellular information system that can be utilized by Minimarket Murah Meriah to build a lowcost minimarket E-catalog product so it is necessary to do a phase analysis, design phase The system uses UML, namely the Use Case Diagram, Activity Diagram, Class Diagram, Sequence Diagram) and finally the testing phase testing program, system testing (Black Box Testing and White Box Testing) and implementation. From the analysis and design of the system, a mobile information system can be made, namely an Android-based E-catalog that can be exploited by minimarkets in Palembang. The catalog application is designed with a simple and user-friendly design to facilitate its use. E-catalog will help the course of promotional activities. Besides, as an innovation promotion for other sellers, there is no need to use print media such as brochures or banner.
\end{abstract}

Keywords : E-Catalog, Android, Minimarket

\begin{abstract}
ABSTRAK
Minimarket Murah Meriah adalah minimarket murah yang ada di Palembang. Minimarket Murah Meriah mendistribusikan produknya melalui media offline dengan brosur dan spanduk sebagai sarana promosi produk. Di era modern perangkat seluler berkembang sangat pesat dan juga evolusi perangkat seluler meningkat seiring dengan jumlah aplikasi platform seluler. Salah satu yang paling berkembang sejauh ini adalah Android. Dengan pesatnya perkembangan teknologi informasi, sebuah bisnis dapat meningkatkan kinerja dan meningkatkan kualitas bisnisnya dengan memberikan kemudahan dan kemudahan bagi pelanggan, tanpa mengeluarkan biaya besar untuk mempromosikan suatu produk. Untuk mengatasi masalah ini, peneliti memerlukan studi untuk membuat sistem informasi seluler yang dapat dimanfaatkan oleh Minimarket Murah Meriah untuk membangun produk E-katalog minimarket murah sehingga perlu melakukan fase analisis, tahap desain Sistem menggunakan UML, yaitu Use Case Diagram, Activity Diagram, Class Diagram, Sequence Diagram) dan akhirnya program pengujian tahap pengujian, pengujian sistem (Black Box Testing dan White Box Testing) dan implementasi. Dari analisis dan desain sistem, sistem informasi mobile dapat dibuat, yaitu E-katalog berbasis Android yang dapat dieksploitasi oleh minimarket di Palembang. Aplikasi katalog dirancang dengan desain yang sederhana dan ramah pengguna untuk memfasilitasi penggunaannya. E-katalog akan membantu jalannya kegiatan promosi. Selain itu, sebagai promosi inovasi untuk penjual lain, tidak perlu menggunakan media cetak seperti brosur atau spanduk.
\end{abstract}

Kata kunci : E-Catalog, Android, Minimarket 


\section{Pendahuluan}

Menjumarnya minimarket untuk memenuhi kebutuhan masyarakat sekitar akan barang-barang yang dibutuhkan sehari-sehari karena faktor jarak yang jauh ke mall atau kepasar tradisional sehingga dengan adanya minimarket ini masyarakat sekitar dapat berbelanja kebutuhannya dari Minimarket yang terdekat Minimarket adalah toko kelontongan swalayan yang menjual produk kebutuhan masyarakat sehari-sehari yang memiliki ciri pembeli dapat memilih sendiri produk-produk yang dibelinya dan membawanya kemeja kasir.Dimeja kasir, kasir memindai (scanning) barcode yang tertera diproduk yang dibeli oleh konsumen secara manual ke komputer setelah selesai secara otomatis komputer akan menghitung jumlah uang yang harus dibayar dan mencetak struk/faktur penjualan yang akan diserahkan kepada pembeli sistem penjualan dan persediaan barang/produk sudah dikomputerisasi melalui perangkat komputer yang akan dikenal dengan istilah Point Of Sales(POS).

Minimarket Murah Meriah adalah sebuah minimarket yang berlokasi dijalan kolonel H.Burlian, $\mathrm{Km} 9$ Palembang, yang menjual barang atau produk kebutuhan masyarakat sehari-hari berkaitan dengan promosi produk-produk yang dijual minimarket kebanyakan minimarket saat ini menggunakan spanduk atau selebaran untuk mempromosikan produk-produk yang dijualnya, menurut peneliti hanya toko serba ada yang besar (yang dikenal dengan istilah hypermarket) yang mampu mencetak brosur atau katalog multi-halaman untuk dibagikan kepengunjung kelemahan cara ini adalah daya jangkau promosi yang terbatas hanya mengenai sasaran pembeli yang kebetulan lewat atau berkunjung ke minimarket tersebut pelanggan yang tidak datang keminimarket tidak akan tahu informasi promosi yang dilakukan pihak minimarket.

Aplikasi e-katalog berbasis android diharapkan dapat mempermudah melakuk promosi selain itu dengan dengan adanya aplikasi e-katalog berbasis android ini diharapkan dapat memperluas daya jangkau promosi.

Hal inilah yang mendorong peneliti ingin membuat "E-Katalog Produk Pada Minimarket Murah Meriah Berbasis Android Untuk Membantu Penjualan" dengan menggunakan metode pengembangan sistem Waterfall sehingga dapat lebih mempermudah pelanggan mengetahui promosi produk minimarket murah meriah.

\section{A. Landasan Teori}

1. Sistem

Sistem adalah kumpulan elemen yang saling berhubungan dan berinteraksi dalam satu kesatuan untuk menjalankan suatu proses pencapaian suatu tujuan utama. [3][27][29]

2. Informasi

Informasi adalah data yang telah diolah menjadi bentuk yang berarti bagi penerimanya dan bermanfaat dalam mengambil keputusan saat itu atau mendatang. [26][27][29]

\section{Sistem Informasi}

Sistem informasi adalah mengumpulkan memproses, menyimpan, menganalisis menyebarkan informasi untuk tujuan tertentu seperti sistem lainnya sebuah sistem informasi terdiri atas input ( data, instruksi) dan output (laporan, kalkulasi). [14][27][29]

4. Katalog dan E-Katalog

Katalog adalah daftar nama-nama tempat dan barangbarang katalog dalam pengertian khusus yakni yang dikenal dalam dunia perpustakaan adalah daftar bahan pustaka atau koleksi yang dimiliki oleh satu atau beberapa perpustakaan yang disusun menurut system tertentu. [18]

\section{Promosi}

Promosi adalah suatu komunikasi informasi penjual dan pembeli yang bertujuan untuk merubah sikap dan tingkah laku pembeli yang sebelumnya tidak mengenal menjadi mengenal sehingga menjadi pembeli dan mengingat produk tersebut. [1][24]

6. Spanduk

Spanduk adalah suatu kain rentang yang isinya propaganda, slogan ataupun berita yang perlu diketahui oleh umum. [7]

7. Brosur

Brosur adalah terbitan tidak berkala yang tidak dijilid kertas, lengkap (dalam satu kali terbitan) memiliki paling sedikit 5 halaman tetapi tidak lebih dari 48 halaman diluar perhitungan sampul. [31]

6. Produk

Produk adalah segala sesuatu yang dapat ditawarkan kepasar untuk memuaskan keinginan atau kebutuhan produk yang dipasarkan meliputi barang fisik acaraacara orang dan gagasan. [1][8]

\section{Minimarket}

Minimarket adalah toko yang mengisi kebutuhan masyarakat akan warung yang berformat modern yang dekat dengan permukiman penduduk sehingga dapat mengungguli toko atau warung. [9]

\section{Android}

Android adalah sistem operasi untuk perangkat mobile berbasis linux yang mencakup sistem operasi middleware dan aplikasi. [21]

\section{Pembahasan}

A. Perancangan Sistem (belum)

1. Use Case Diagram Sistem Usulan

Use case diagram adalah representasi dari interaksi pengguna dengan sistem yang menunjukkan hubungan antara pengguna dan kasus penggunaan yang berbeda dimana pengguna terlibat.[12] 


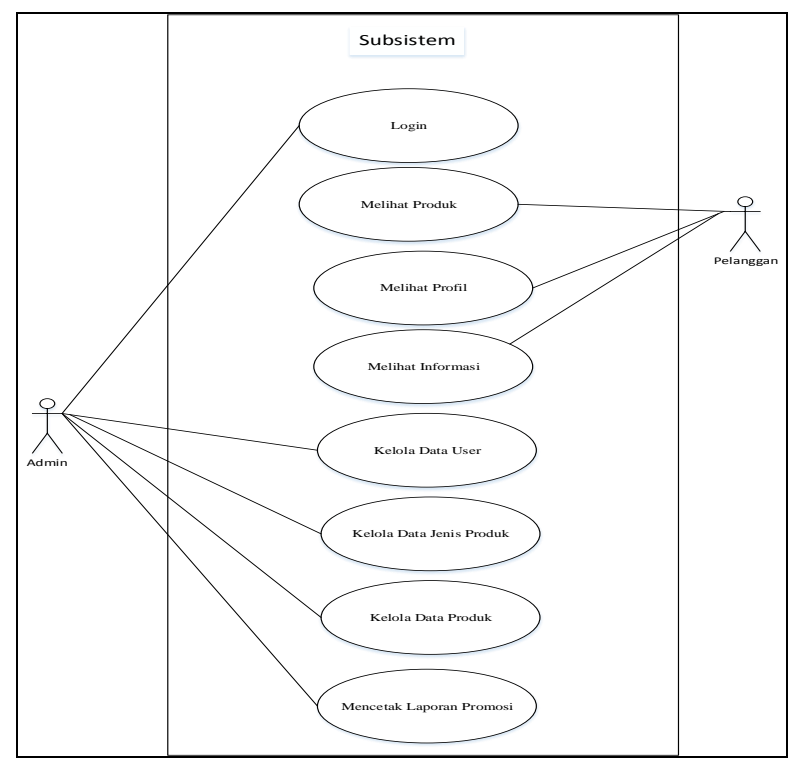

Gambar 1. Use Case Diagram

2. Activity Diagram Sistem Usulan

Activity diagram menggambarkan berbagai alir aktivitas dalam sistem yang sedang dirancang, bagaimana masing-masing alir berawal, decision yang mungkin terjadi, dan bagaimana mereka berakhir.[17][29]

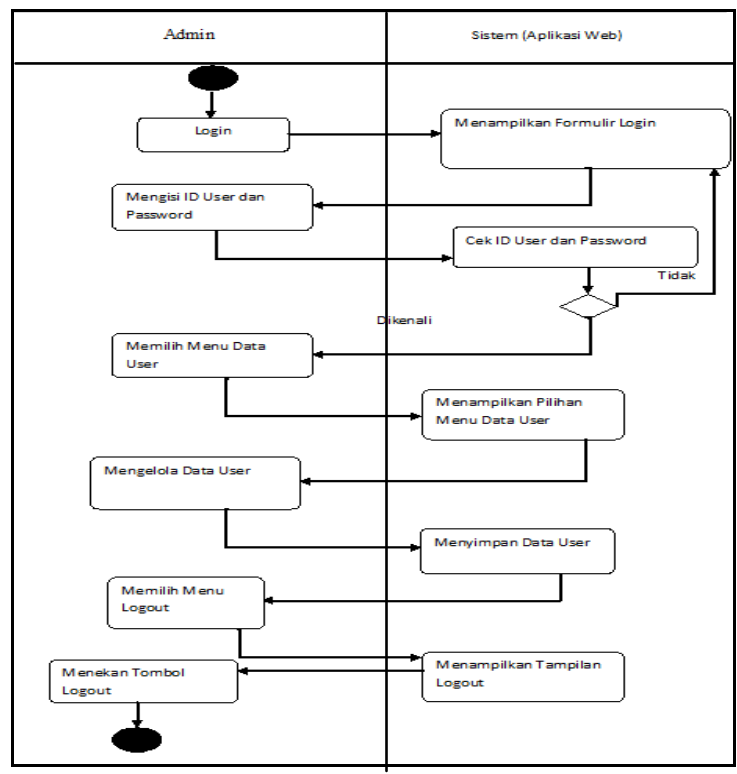

Gambar 2. Activity Diagram

3. Sequence Diagram Sistem Usulan

Sequence diagram (diagram urutan) adalah suatu diagram yang memperlihatkan atau menampilkan interaksi-interaksi antar objek di dalam sistem yang disusun pada sebuah urutan atau rangkaian waktu.[27][29]

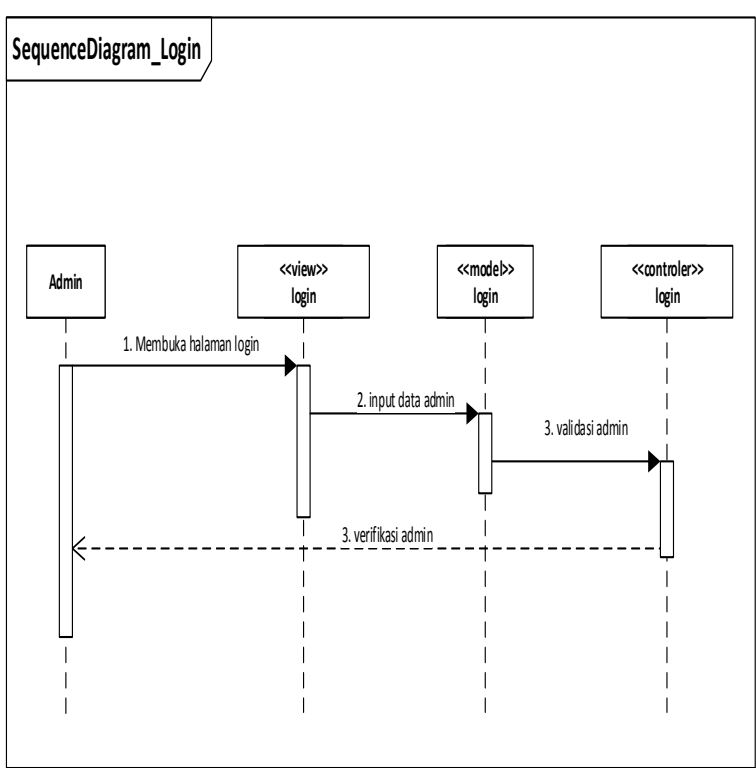

Gambar 3. Sequence Diagram

4. Class Diagram Sistem Usulan

Class Diagram adalah model statis yang menggambarkan struktur dan deskripsi class serta hubungannya antara class. Class diagram mirip entity relathionship diagram pada perancangan database, bedanya pada entity relathionship diagram tidak terdapat operasi/metode tapi hanya atribut. Class terdiri dari nama kelas, atribut dan operasi/metode.[23][30]

\begin{tabular}{||l|l|}
\hline \multicolumn{1}{|l|}{} & \multicolumn{1}{|c|}{ Produk } \\
\hline \multicolumn{1}{|l|}{ Kategori } \\
\cline { 1 - 1 }
\end{tabular}

Gambar 4. Class Diagram

\section{B. Implementasi}

Adapun hasil atau implementasi dari rancangan ekatalog produk pada minimarket murah meriah sebagai berikut:

1. Tampilan Spalsh Screen E-Katalog Produk Berbasis Android

Halaman splash screen merupakan halaman tampilan utama pada e-katalog. 


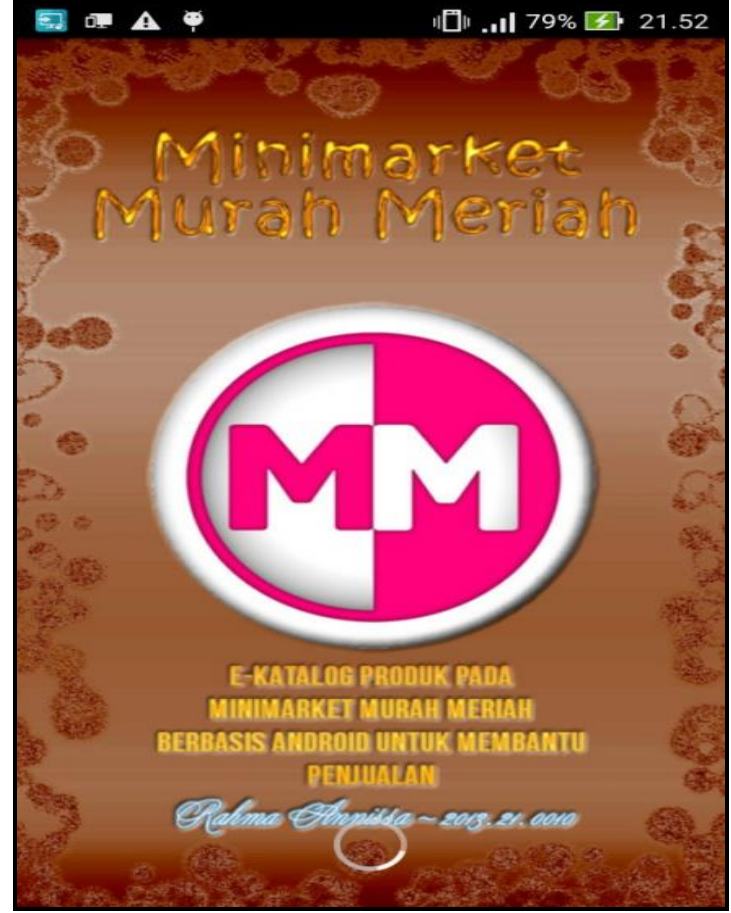

Gambar 5. Screen E-Katalog

2. Tampilan Layar Menu E-Katalog Produk Berbasi Android

Halaman tampilan layar merupakan halaman tampilan produk, tampilan profil, tampilan informasi, tampilan mengenai aplikasi, dan tampilan keluar.

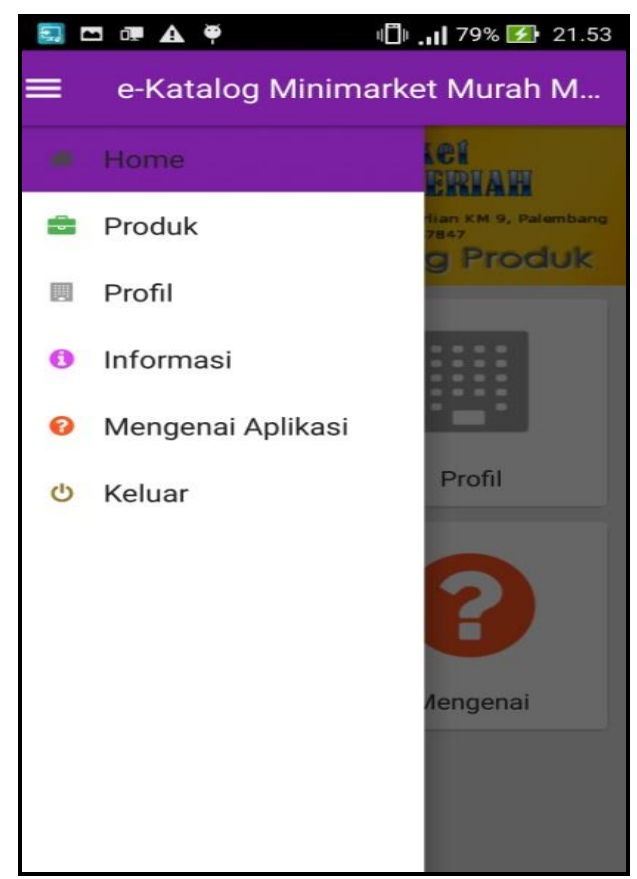

Gambar 6. E-Katalog Produk

3. Tampilan Pilihan Menu Pada Sistem Informasi Berbasi Android

Pada tabel dibawah ini disajikan daftar pilihan aktivitas pada e-katalog produk minimarket murah meriah berbasis android.

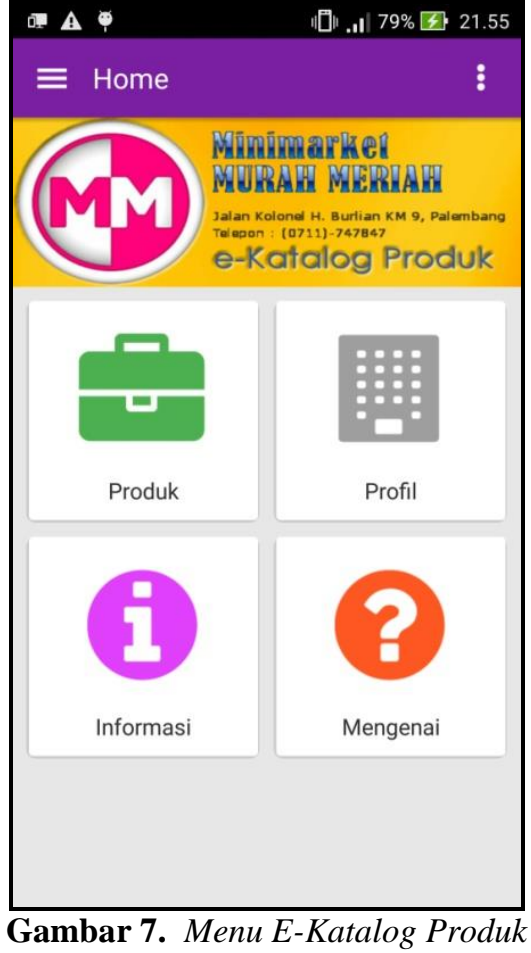

4. Tampilan Layar Kategori Atau Jenis Produk

Pilihan ini akan menampilkan halaman yang berisi informasi mengenai daftar produk minimarket murah meriah

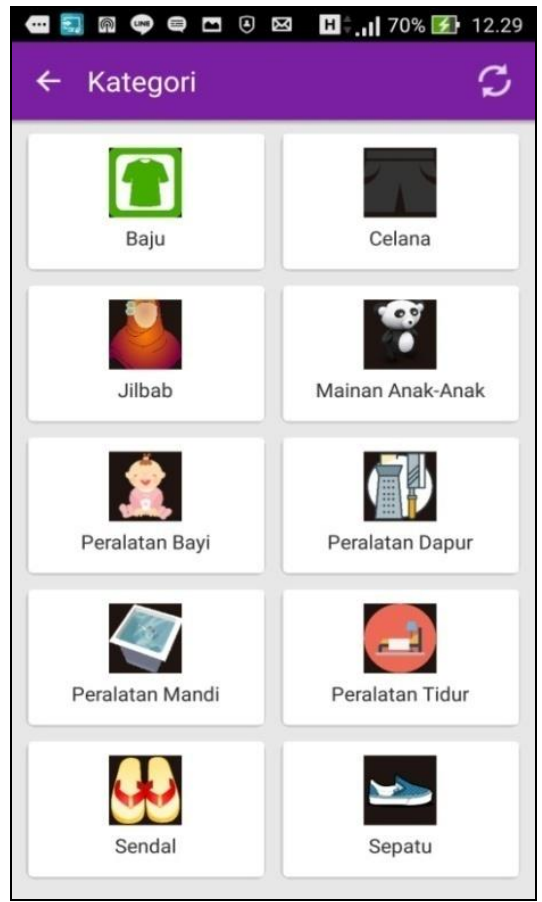

Gambar 8. Kategori atau Jenis Produk

5. Tampilan Layar Produk

Tampilan Layar Produk pilihan ini akan menampilkan halaman yang berisi satu file tentang pengelompokan kategori produk yang sama pada EKatalog Produk Minimarket Murah Meriah. 

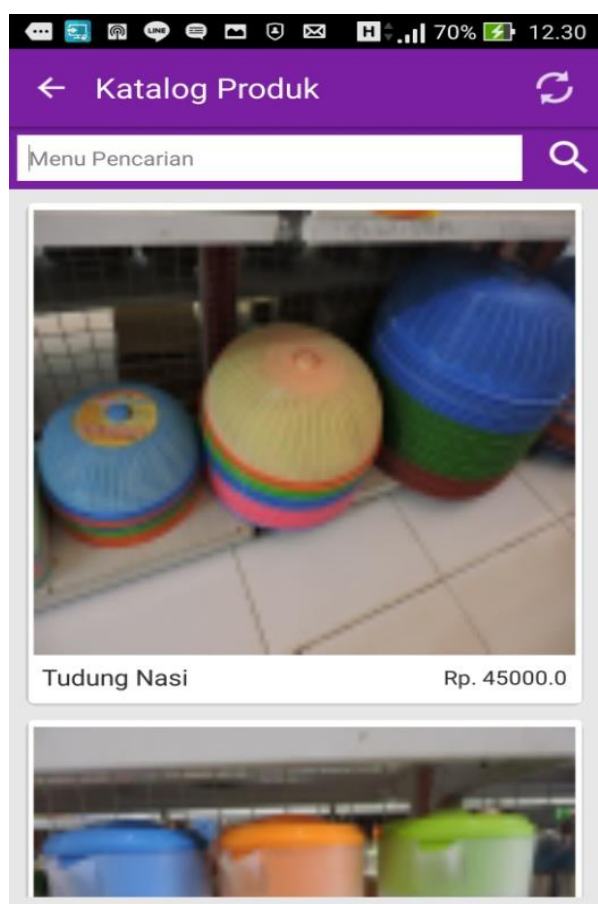

Gambar 9. Produk

6. Tampilan Layar Produk Menu Detail

Pilihan ini akan menampilkan halaman yang berisi informasi mengenai menu detail rincian produk dari Minimarket Murah Meriah.

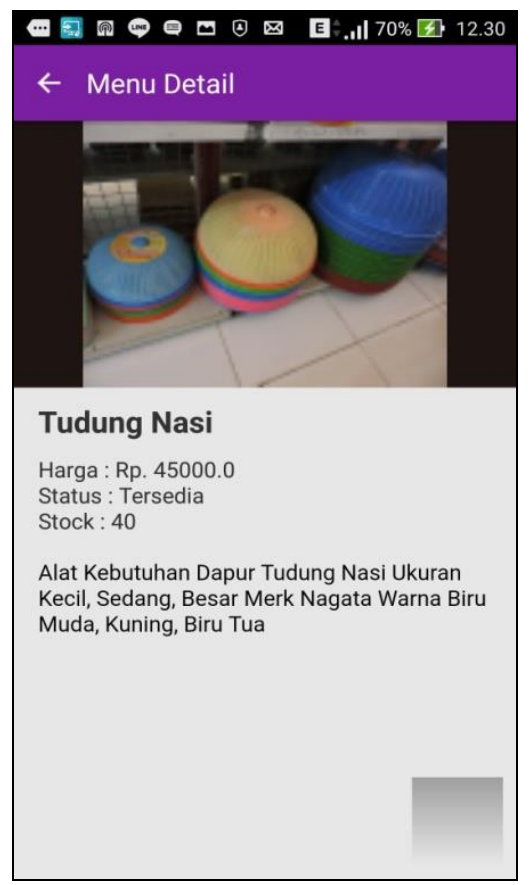

Gambar 10. Produk

7. Tampilan Halaman Pilihan Profil

Pilihan ini akan menampilkan halaman yang berisi informasi mengenai profil dari Minimarket Murah Meriah.

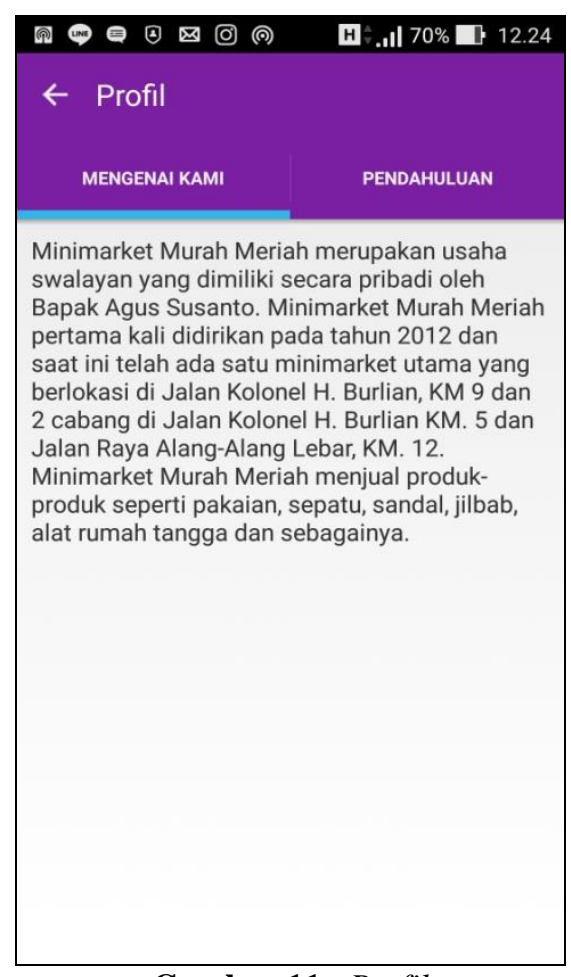

Gambar 11. Profil

8. Tampilan Halaman Web Awal (Homepage) EKatalog Produk Minimarket Murah Meriah

E-katalog produk berbasis web jika dijalankan/dipanggil dalam web browser akan menampilkan tampilan seperti pada gambar dibawah ini.

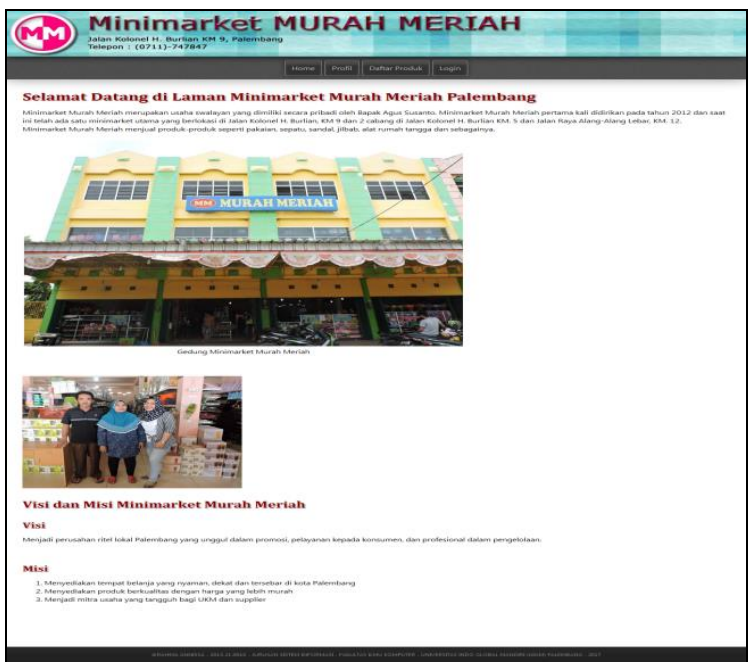

Gambar 12. Homepage E-Katalog

9. Tampilan Halaman Daftar Produk

Halaman ini menampilkan informasi daftar produk yang dijual oleh Minimarket Murah Meriah. 


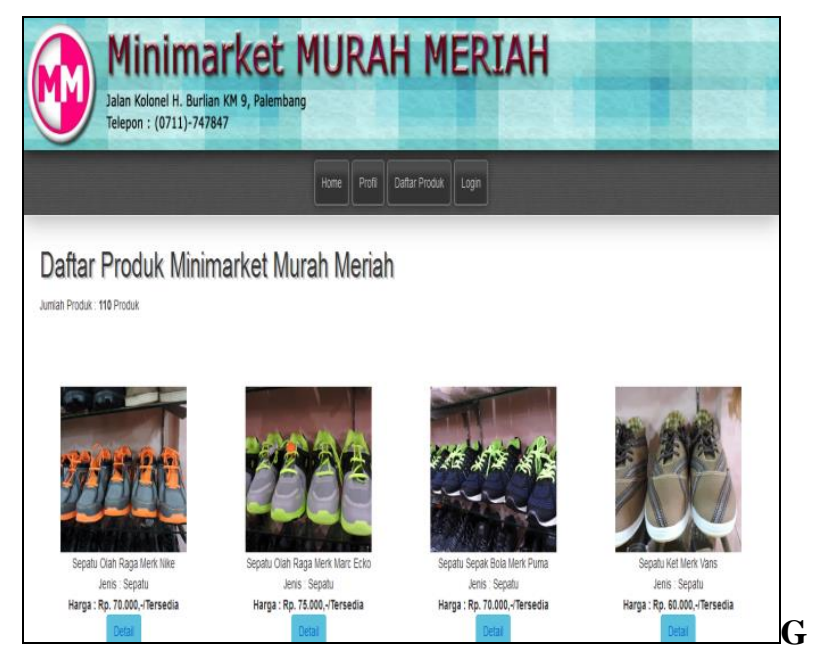

ambar 13. Daftar Produk

10. Tampilan Halaman Rincian Produk

Ketika pengguna atau pengunjung mengklik link yang ada pada tabel daftar produk maka pengguna atau pengunjung akan dibawa menuju halaman rincian produk yang dimaksud.

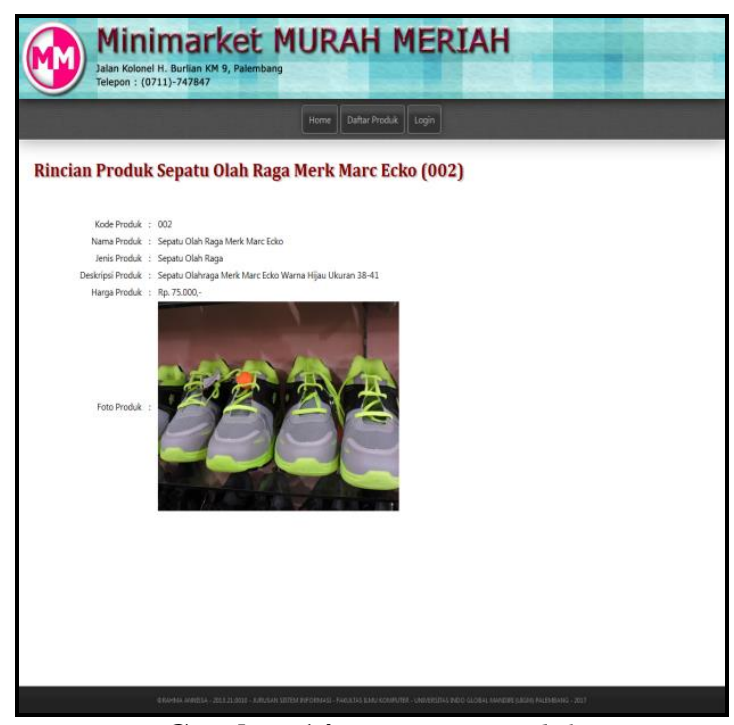

Gambar 14. Rincian Produk

11. Tampilan Halaman Beranda User

Jika pengguna telah mengisikan id user dan password yang sesuai, pemilik akan diarahkan ke halaman beranda user.

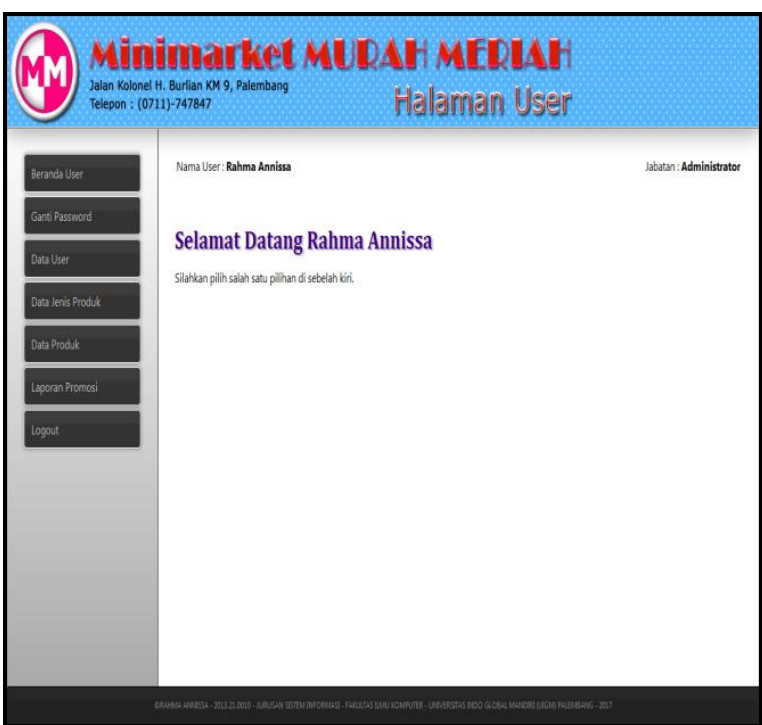

Gambar 15. Beranda User

\section{Tampilan Halaman Ganti Password}

Halaman ini menyediakan fasilitas bagi user pemilik untuk mengganti password lamanya dengan password yang baru. Mengganti password dianjurkan dilakukan secara rutin untuk menjaga keamanan sistem informasi.

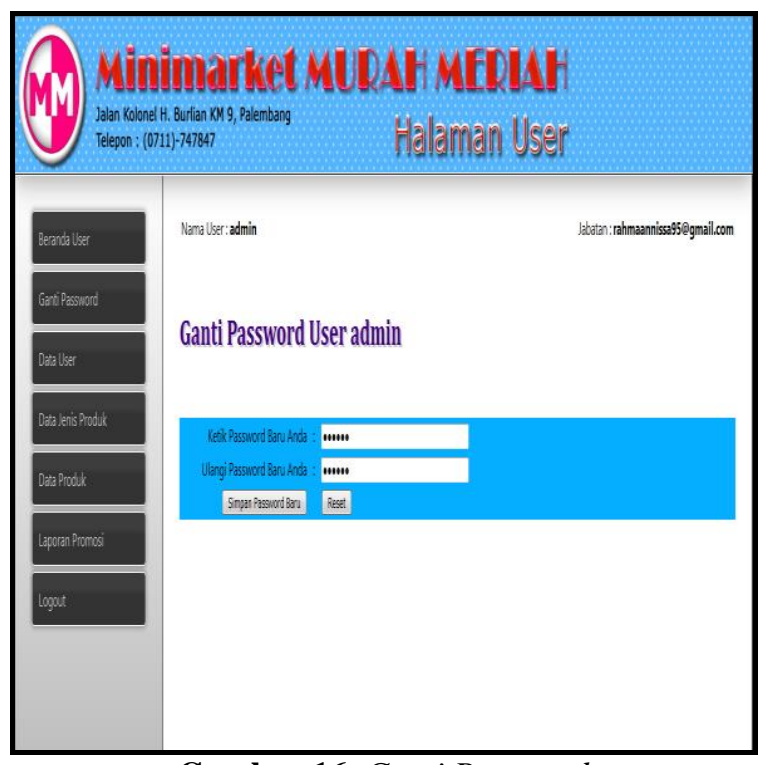

Gambar 16. Ganti Password

13. Tampilan Halaman Data User

Halaman ini menyediakan fasilitas bagi user untuk mengisi, mengedit, melihat dan menghapus data user/pengguna aplikasi. 


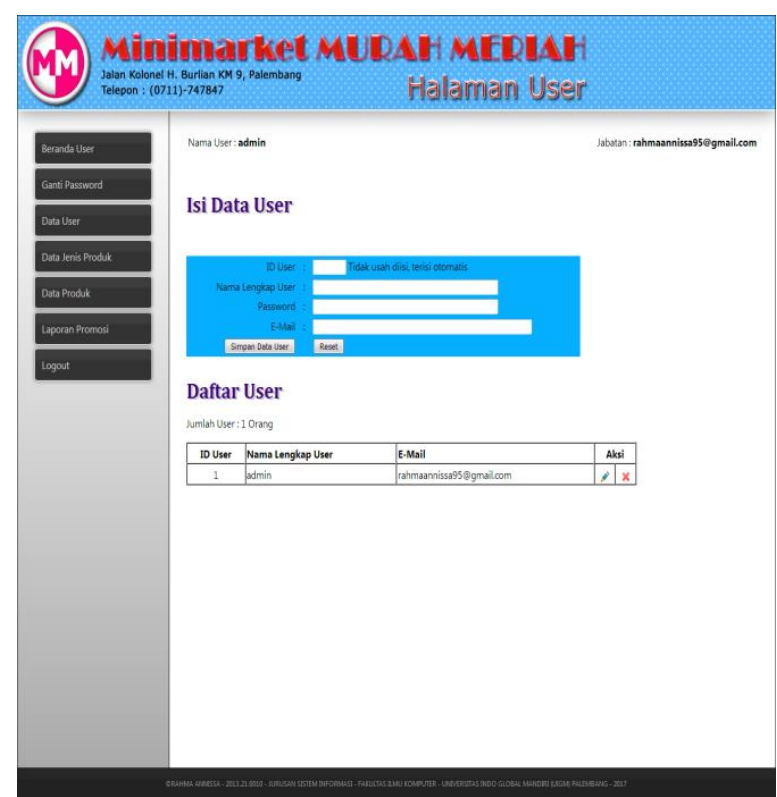

Gambar 17. Data User

14. Tampilan Halaman Data Jenis Produk

Halaman ini menyediakan fasilitas bagi user untuk mengisi, mengedit, melihat dan menghapus data jenis produk yang ada di Minimarket Murah Meriah.

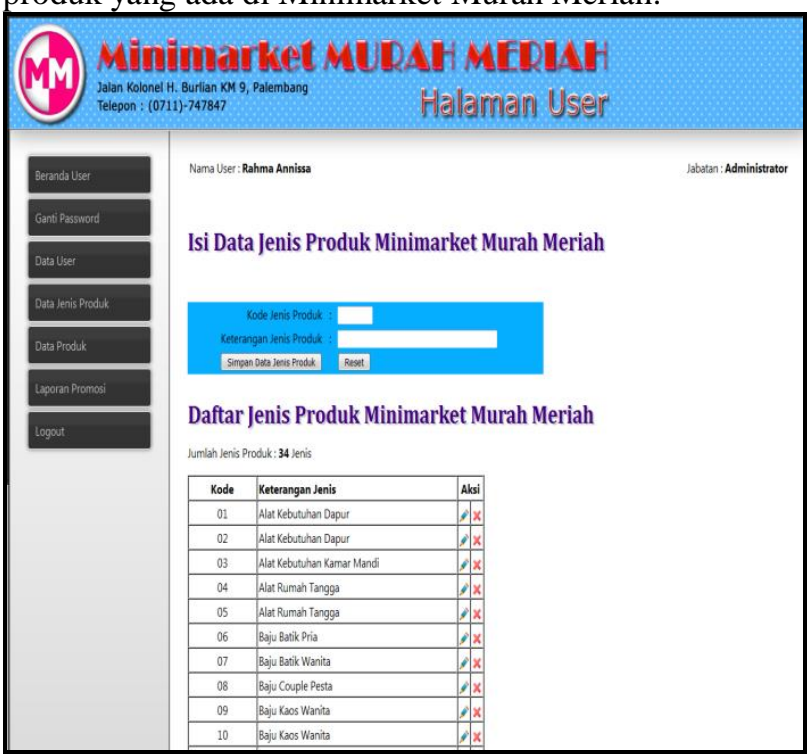

Gambar 18. Data Jenis Produk

15. Tampilan Halaman Data Produk

Halaman ini menyediakan fasilitas bagi user pemilik untuk mengisi, mengedit, melihat dan menghapus data produk yang dijual oleh Minimarket Murah Meriah.

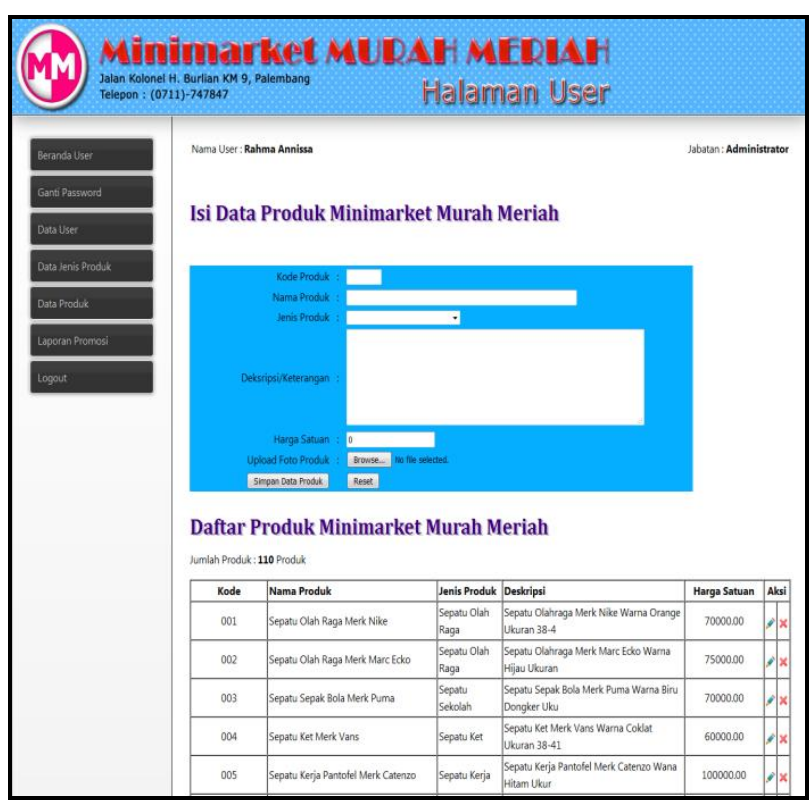

Gambar 19. Data Produk

16. Tampilan Halaman Laporan Promosi

Halaman ini menyediakan fasilitas bagi user untuk melihat laporan dari kegiatan promosi yang dilaksanakan guna meningkatkan penjualan di Minimarket Murah Meriah.

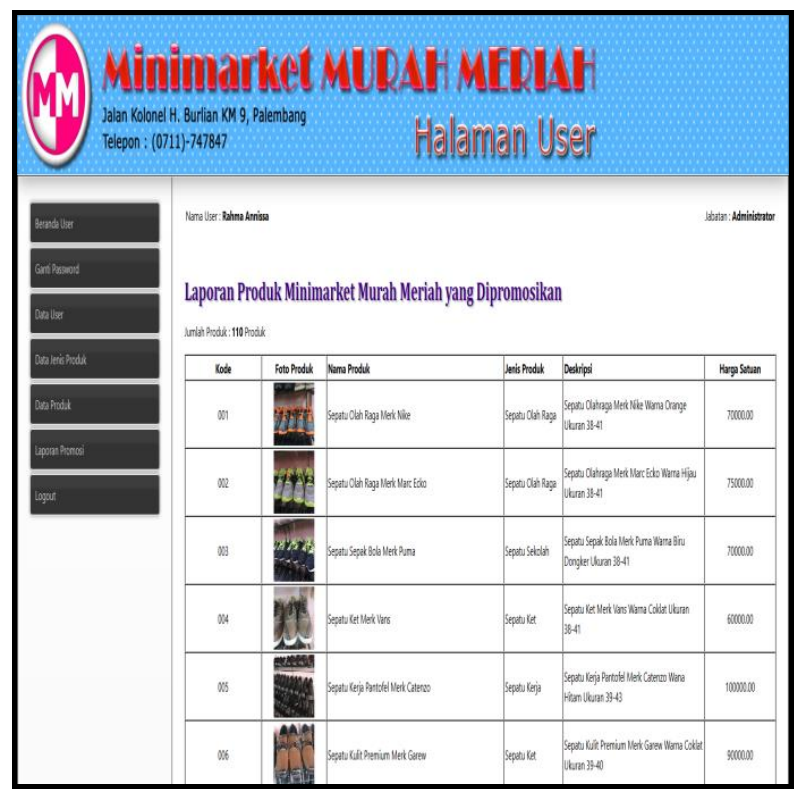

Gambar 20. Laporan Promosi

17. Tampilan Halaman Cetak Laporan Promosi

Halaman ini menyediakan fasilitas bagi user untuk cetak laporan dari kegiatan promosi yang dilaksanakan guna mengetahui laporan penjualan di Minimarket Murah Meriah. 


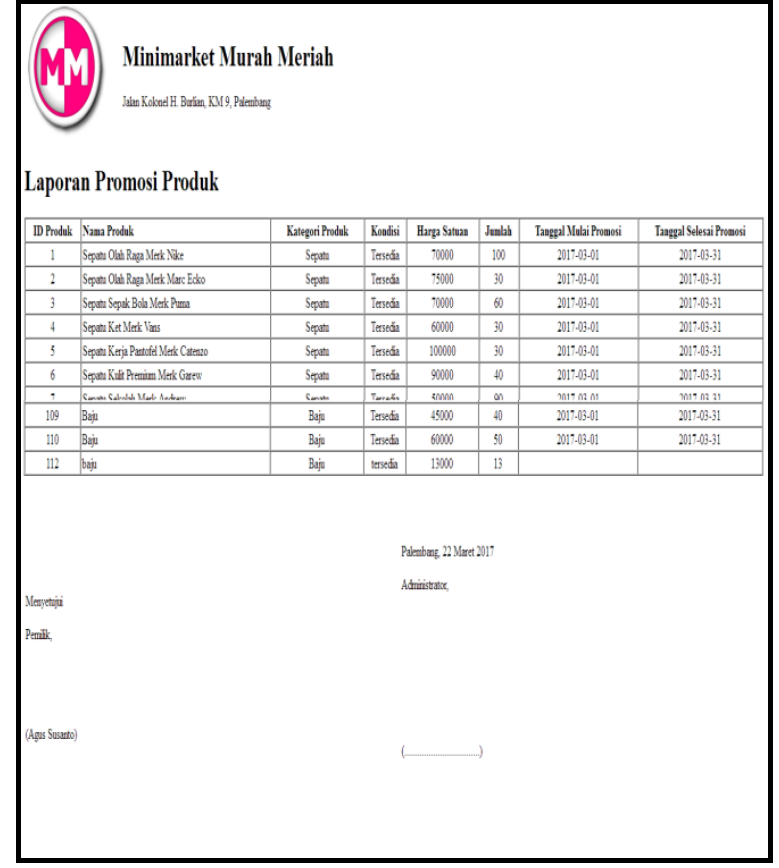

Gambar 21. Laporan Promosi

\section{Kesimpulan}

Berdasarkan uraian dan pembahasan pada bab-bab sebelumnya mengenai E-Katalog Produk Pada Minimarket Murah Meriah Berbasis Android Untuk Membantu Penjualan, maka peneliti menarik kesimpulan sebagai berikut :

1. E-katalog produk pada Minimarket Murah Meriah yang dibangun bisa mempermudah Pihak Perusahaan dalam melakukan penjadwalan Promosi.

2. Dengan dibangunnya aplikasi E-Katalog bisa memperluas daya jangkau promosi yang ada di Minimarket Murah Meriah.

Berdasarkan uraian dan pembahasan pada bab-bab sebelumnya mengenai E-Katalog Produk Pada Minimarket Murah Meriah Berbasis Android Untuk Membantu Penjualan, maka peneliti mencoba memberikan saran-saran sebagai berikut :

1. Penelitian ini perlu dikembangkan lebih lanjut dengan cara menambhakan fasilitas untuk bertransaksi melalui aplikasi E-Katalog Android ini, menambahkan fasilitas berkomunikasi dengan pihak produsen, dan sebagainya

2. E-Katalog Produk Minimarket MurahMeriah yang berbasis Android dan web diimplementasikan dalam lingkup lokal (aplikasi web diimplementasikan di satu komputer dan smartphone berbasis Android terkoneksi ke komputer tersebut). Perlu kiranya untuk pengembangan lebih lanjut implementasi EKatalog ini dilakukan secara real-time sehingga terlihat benar manfaatnya.

\section{Daftar Pustaka.}

Alma, Buchari. 2006. Pemasaran dan Pemasaran Jasa. Alfabeta. Bandung.
Arief, M.Rudianto. 2011.Pemrograman WEB Dinamis Menggunakan PHP dan MySQL C.V ANDI OFFSET.Yogyakarta.

Fathansyah. 2012. Basis Data. Informatika. Bandung.

Halim, Relung. 2013. Pembuatan E-Katalog Dan ELelang Pada Sistem Android.

Halim, Relung. 2013.Pembuatan ekatalog dan e-lelang Pada sistem Android. Jurnal Ilmiah Mahasiswa Universitas Surabaya Vol. 2 No. 1. Diakses tanggal 20-12-2016 16.15.

Keller dan Kotler. 2007. Manajemen Pemasaran.Edisi 12. Jilid 1. PT.Indeks. Jakarta.

Ma'ruf, Hendri. 2005. Pemasaran Ritel.Jakarta : PT Gramedia Pustaka Utama. Jakarta.

Minimarket, Murah, Meriah. 2016.

Munawar. 2005. Pemodelan Visual dengan UML. Graha Ilmu. Yogyakarta.

Nugroho, Bunafit. 2006. Membuat Aplikasi Sistem Pakar dengan PHP dan MySQL dengan PHP dan MySQL dengan Editor Dreamweaver.Ardana Media.Yogyakarta.

Pratama. 2014. Sistem Informasi dan Implementasinya. Informatika. Bandung.

Pressman. 2013. Software Engineering: A Practitioner's Approach. 8th Edition. McGraw-Hill. USA.

Pressman, S, Roger. 2014. Rekayasa Perangkat Lunak. Yogyakarta : Andi.

Rahmi, Lailatul. 2016. Apa Itu e-Katalog.

Safaat, Nazruddin. 2011. Android Studio (Pemograman Aplikasi Mobile Smartphone dan Tablet PC Berbasis Android). Informatika. Bandung.

Saladin, Djaslim dan Oesman, Marty, Yevis. 2002. Perilaku Konsumen dan Pemasaran Strategik. Balai Pustaka.Jakarta. 